\title{
Efektivitas Penerapan Metode Bermain Peran Makro Terhadap Perkembangan Bahasa Lisan Anak Di Taman Kanak-Kanak Darul Falah Kota Padang
}

\author{
Maidita Putri ${ }^{1}$ \\ maiditaputri1996@gmail.com
}

Rakimahwati

\section{Zulminiati}

\begin{abstract}
This study aims to find out how effective of the application of macro roles playing methods for the development of the oral language of children in the kindergarten of Darul Falah Padang city. This research uses quantitative approach with quasi-experiment research type. The study population is students in the kindergarten of Darul Falah Padang city and the sampling technique is purposive sampling. The data collection technique uses a test in the form of a statement of 4 statement items. Assessment techniques in this study use rating scale and the data is processed by difference test (t-test) and the effect size test with Cohen's formula $d$ to find out the magnitude of the influence.Based on the calculation of the t-test (t-test) obtained $t_{\text {count }}$ of 3,1645 while the $t_{\text {table }}$ is a 2,10092 at the real level $\alpha=0,05$ so that $t_{\text {count }}>t_{\text {table }}$ and the effect size tets of the $t$-test is obtained for 1,488 . Thus it can be concluded that macro roles playing methods are effective against the development of children's oral language in the kindergarten of Darul Falah Padang city.
\end{abstract}

Keywords: Application of macro role playing methods; Oral language development

\section{PENDAHULUAN}

Anak usia dini adalah individu yang sedang mengalami proses pertumbuhan dan perkembangan yang pesat. Masa usia dini disebut juga dengan masa golden age (usia emas) yaitu usia yang berharga dan menentukan masa depan usia selanjutnya. Usia tersebut merupakan fase kehidupan yang unik dengan karakteristik yang khas, baik secara fisik, psikis, sosial dan moral. Setiap anak akan mengalami tumbuh kembang secara fleksibel dan berkesinambungan. Pendidikan sebagai upaya untuk memajukan budi pekerti, pikiran serta jasmani anak agar dapat memajukan kesempurnaan hidup dan menghidupkan anak yang selaras dengan alam dan masyarakat. Pendidikan dikelompokkan ke dalam pendidikan formal dan pendidikan non formal. Pendidikan formal sudah dapat diberikan kepada anak sejak anak berusia dini. Pendidikan anak usia dini jalur formal yaitu Taman Kanakkanak. Taman Kanak-kanak yaitu pada anak yang berusia 4-6 tahun.

Salah satu aspek perkembangan yang penting untuk dikembangkan pada anak adalah perkembangan bahasa. Perkembangan bahasa merupakan salah satu aspek pengembangan kemampuan dasar anak yang sangat penting terutama adalah perkembangan bahasa lisan. Perkembangan bahasa lisan anak sangat penting untuk dikembangkan karena dengan berbahasa lisan anak dapat berkomunikasi dengan lingkungan sekitar. 
Menurut Pudjaningsih (2013:85-86), mengatakan bahwa bahasa lisan merupakan kegiatan mengekspresikan pikiran, ide, maupun perasaan. Selain itu, bahasa lisan anak meningkat sesuai dengan usia anak dimana perbendaharaan kata anak akan lebih banyak untuk digunakan ketika berkomunikasi dengan teman sebayanya. Anak usia Taman Kanak-kanak berada pada fase dimana anak telah dapat mengungkapkan

keinginannya, penolakannya, maupun pendapatnya melalui bahasa lisan. Namun sering kita temukan anak yang belum memiliki kemampuan bahasa lisan yang optimal sesuai dengan karakteristik kemampuan bahasa lisan anak usia Taman Kanak-kanak. Untuk itu sangat diperlukan peran pendidik dalam pemberian rangsangan atau stimulus agar bahasa lisan anak dapat berkembang dengan optimal dalam kegiatan pembelajaran.

Kegiatan untuk mengembangkan perkembangan bahasa lisan pada anak usia Taman Kanak-kanak dapat diberikan melalui berbagai metode pembelajaran. Metode pembelajaran yang harus dipersiapkan yaitu dengan memilih metode pembelajaran untuk mengembangkan kemampuan berbahasa anak yaitu menggunakan metode bermain peran makro dengan berbantuan media sederhana untuk meningkatkan kemampuan berbahasa anak. Pembelajaran akan berjalan efektif dan efisien apabila menggunakan metode pembelajaran dengan baik dan sesuai dengan kondisi anak. Dimana, metode adalah cara atau langkah yang dilakukan pendidik dalam pembelajaran. Menurut Susanto (2017:120) menyebutkan bahwa metode pembelajaran adalah suatu cara atau prosedur yang ditempuh pendidik dalam mengelola pembelajaran yang efektif dan efisien. Perkembangan bahasa lisan anak belum berkembang sebagaimana yang diharapkan. Dimana, terlihat masih banyak anak yang pasif ketika berkomunikasi dengan anak lainnya sehingga anak belum bisa mengungkapkan keinginannya, pendapatnya bahkan idenya ketika bermain dengan teman sebayanya dan sebagian anak belum bisa berkomunikasi secara lancar dengan lafal yang benar misalnya menyebutkan identitasnya dimulai dari namanya sendiri hingga tempat tinggalnya. Hal tersebut mengakibatkan pembendaharaan kata anak menjadi sedikit dan anak tidak mau berkomunikasi dengan temannya saat bermain. Penelitian ini bertujuan untuk mengetahui seberapa efektif penerapan metode bermain peran makro terhadap perkembangan bahasa lisan anak di Taman Kanak-kanak Darul Falah Kota Padang.

Para ahli memiliki definisi yang berbeda tentang bahasa lisan. Menurut Smidt dalam Akil dan Winata (2017:96), mengatakan bahwa bahasa lisan adalah sistem komunikasi yang digunakan oleh manusia untuk mengekspresikan pemikiran anak. Sedangkan, menurut Dwiantari, dkk (2016) mengatakan bahwa anak telah dapat mengungkapkan keinginannya, penolakannya, maupun pendapatnya dengan bahasa lisan. Bahasa lisan sudah dapat digunakan anak sebagai alat berkomunikasi. Selanjutnya Pudjaningsih (2013:85-86), mengatakan bahwa bahasa lisan merupakan kegiatan mengekspresikan pikiran, ide, maupun perasaan. Selain itu, bahasa lisan anak meningkat sesuai dengan usia anak dimana perbendaharaan kata anak akan lebih banyak untuk digunakan ketika berkomunikasi dengan teman sebayanya. Berdasarkan pendapat ahli di atas, maka disimpulkan bahwa perkembangan bahasa lisan anak usia dini adalah bahasa yang digunakan anak dimana anak sudah bisa mengatakan dan mengekspresikan keinginannya dan pendapatnya secara langsung ketika sedang berkomunikasi dengan orang lain terutama teman sebayanya disaat bermain. 
Perkembangan bahasa lisan anak dapat dikembangkan dengan metode bermain peran. Dimana, metode bermain peran adalah suatu metode pembelajaran dengan melakonkan atau memerankan tokoh dalam suatu cerita. Metode bermain peran terbagi dua yaitu metode bermain peran makro dan metode bermain peran mikro. Metode bermain peran makro merupakan salah satu jenis dari metode bermain peran. Bermain peran makro merupakan bermain peran yang sesungguhnya dengan alat permainan yang besar dan dimainkan dengan lebih dari 2 anak. Menurut Safriayani, dkk (2011:9) menyatakan bahwa main peran makro adalah anak-anak berperan sebagai seseorang atau sesuatu. Dalam hal ini anak memerankan sendiri peran yang ingin ia mainkan. Sedangkan Menurut Rumilasari, Tegeh dan Ujianti (2016), menyatakan bahwa metode bermain peran makro yaitu anak bermain peran sesungguhnya yang sifatnya kerjasama dan dilakukan oleh 2 orang atau lebih. Dan juga Madyawati (2016:157) menyatakan bahwa bermain peran makro adalah anak berperan sesungguhnya dan menjadi seseorang atau sesuatu. Saat anak memiliki pengalaman sehari-hari dengan main peran makro (tema sekitar kehidupan nyata), anak belajar banyak keterampilan pra-akademis, seperti: mendengarkan, tetap dalam tugas, menyelesaikan masalah, dan bermain kerja sama dengan yang lainnya. Berdasarkan pendapat di atas, maka dapat disimpulkan bahwa metode bermain peran makro adalah metode bermain peran dimana anak berperan sesungguhnya dengan menjadi seseorang sesuai dengan peran yang ingin anak mainkan dengan beranggotakan lebih dari 2 orang dengan sifat kerja sama.

Penerapan metode bermain peran makro yang digunakan dalam perkembangan bahasa lisan anak dalam mengembangkannya berdasarkan langkahlangkah yang sudah di tetapkan dan menggunakan alat permainan yang mendukung pelaksanaan pembelajaran agar berjalan secara optimal. Dalam bermain ditentukan terlebih dahulu tema yang akan dikembangkan. Tema yang diambil dalam pembelajaran sesuai dengan kurikulum yang ada di sekolah tersebut. Tema yang diambil oleh peneliti dalam penelitian ini adalah tema kebutuhanku dengan subtema minuman dengan kegiatan restoran minuman. Penelitian juga membutuhkan media dan skenario agar pembelajarannya lebih terstruktur. Melalui penerapan metode bermain peran makro diharapkan dapat mengembangkan perkembangan bahasa lisan anak dengan yang diharapkan dan berkembang secara maksimal. Penelitian ini bertujuan untuk mengetahui seberapa efektif penerapan metode bermain peran makro terhadap perkembangan bahasa lisan anak di Taman Kanak-kanak Darul Falah Kota Padang.

\section{METODE PENELITIAN}

Penelitian ini termasuk jenis penelitian ini adalah penelitian kuantitatif dengan metode eksperimen dalam tipe Quasy Eksperiment. Menurut Sugiyono (2015:107) mengatakan bahwa metode eksperimen adalah metode penelitian yang digunakan untuk mencari pengaruh perlakuan tertentu terhadap yang lain dalam kondisi yang terkendalikan. Populasi dalam penelitian ini adalah peserta didik di Taman Kanak-kanak Darul Falah Kota Padang. Taman Kanak-kanak Darul Falah Kota Padang ini di bawah pimpinan lbu Amyeni S.Pd dan diasuh oleh 4 orang tenaga pendidik. Taman Kanak-kanak Darul Falah Kota Padang memiliki jumlah siswa sebanyak 48 orang yang terbagi ke dalam 4 kelompok belajar yaitu: B1 15 orang, B2 13 orang, B3 10 orang dan B4 10 orang.

Sampel yang dilakukan dalam penelitian ini adalah teknik Sampling Purposive. Menurut Sugiyono (2015:124), Sampling Purposive adalah teknik penentuan sampel dengan pertimbangan 
tertentu. Untuk menentukan sumber data, maka pengambilan sampelnya berdasarkan daerah populasi yang ditetapkan. Teknik analisis data yang digunakan dalam penelitian ini adalah membandingkan perbedaan dari dua rata-rata nilai, sehingga dilakukan dengan uji $t$ (t-tes) dan dilanjutkan dengan effect size-t menggunakan cohen's $d$. Namun sebelum itu, terlebih dahulu melakukan uji normalitas dan uji homogenitas.

Titik tolak dari penyusunan instrumen adalah variabel-variabel penelitian yang ditetapkan untuk diteliti, selanjutnya diberikan indikator yang akan diukur. Dari indikator ini kemudian dijabarkan menjadi butir-butir (item) pertanyaan atau pernyataan. Untuk memudahkan penyusunan instrumen, maka digunakan kolom pengembangan instrumen atau kisikisi instrumen. Sebagaimana dikatakan Menurut Arikunto (2010:205), menurut pengertiannya, kisi-kisi adalah sebuah tabel menunjukkan hubungan antara hal-hal yang disebutkan dalam baris dengan hal-hal yang disebutkan dalam kolom. Kisi-kisi penyusunan instrumen menunjukkan kaitan antara variabel yang diteliti dengan sumber data dari mana data akan diambil, metode yang digunakan, dan instrumen yang disusun.

\section{HASIL DAN PEMBAHASAN Hasil}

Data yang dideskripsikan dalam penelitan ini terdiri dari dua kelompok yaitu kelompok eksperimen (B3) dan kelompok kontrol (B4). Masing-masing kelompok eksperimen dan kontrol memiliki dua nilai yaitu nilai pre-test dan post-test. Nilai pretest diambil sebelum dilakukan treatmen sedangkan nilai post-test diambil setelah dilakukannya treament sebanyak tiga kali. Dimana hasil nilai pre-test dan post-test terlihat pada tabel 1
Tabel 1. Rekapitulasi Hasil Pre-test Perkembangan Bahasa Lisan Anak di Kelas Eksperimen dan Kelas Kontrol

Variabel

Pembelajaran

\begin{tabular}{cc}
\hline Metode & Metode \\
Bermain & Bercakap- \\
Peran & cakap \\
Makro & Kontrol \\
Eksperimen & (B4) \\
(B3) & \\
\hline
\end{tabular}

\begin{tabular}{lll}
\hline $\mathbf{N}$ & 10 & $\mathbf{1 0}$ \\
\hline Nilai Tertinggi & 75 & $\mathbf{7 5}$ \\
\hline Nilai Terendah & 50 & $\mathbf{5 0}$ \\
\hline Jumlah nilai & 612,5 & $\mathbf{6 0 6 , 2 5}$ \\
\hline Median & 62,5 & $\mathbf{6 2 , 5}$ \\
\hline Rata-Rata & 61,25 & $\mathbf{6 0 , 2 5}$ \\
\hline SD & 9,81 & $\mathbf{8 , 0 6}$ \\
\hline SD2 & $\mathbf{9 6 , 2 3}$ & $\mathbf{6 4 , 9 6}$ \\
\hline
\end{tabular}

Berdasarkan tabel 1 di atas, kelas eksperimen dengan jumlah anak 10 orang memperoleh nilai tertinggi 75 dan nilai terendah 50. Dari nilai anak kelas eksperimen ini diperoleh jumlah nilai secara keseluruhan yaitu 612,5, median sebesar 62,5 dengan rata-rata nilainya sebesar 61,25 standar deviasinya 9,81 dan nilai variansnya 96,23 . Sedangkan kelas kontrol dengan jumlah anak 10 orang memperoleh nilai tertinggi 75 dan nilai terendah 50 . Dari nilai anak kelas kontrol ini diperoleh jumlah nilai secara keseluruhan yaitu 606,25, median sebesar 62,5 dengan rata-rata nilainya sebesar 60,25 standar deviasinya 8,06 dan nilai variansnya 64,96 . 
Tabel 2. Rekapitulasi Hasil Post-test Perkembangan Bahasa Lisan Anak di Kelas Eksperimen dan Kelas Kontrol

Variabel

\begin{tabular}{cc}
\multicolumn{2}{c}{ Pembelajaran } \\
\hline Metode & Metode \\
Bermain & Bercakap- \\
Peran & cakap \\
Makro & Kontrol \\
Eksperimen & (B4) \\
(B3) &
\end{tabular}

\begin{tabular}{lll}
\hline $\mathbf{N}$ & 10 & 10 \\
\hline Nilai Tertinggi & 100 & 93,75 \\
\hline Nilai Terendah & 81,25 & 75 \\
\hline Jumlah nilai & 925 & 825 \\
\hline Median & 95 & 82,8 \\
\hline Rata-Rata & 92,5 & 82,5 \\
\hline SD & $\mathbf{7 , 2 8}$ & 6,12 \\
\hline SD2 & $\mathbf{9 6 , 2 3}$ & $\mathbf{6 4 , 9 6}$ \\
\hline
\end{tabular}

Berdasarkan tabel 2 di atas, kelas eksperimen dengan jumlah anak 10 orang memperoleh nilai tertinggi 100 dan nilai terendah 81,25. Dari nilai anak kelas eksperimen ini diperoleh jumlah nilai secara keseluruhan yaitu 925, median sebesar 95 dengan rata-rata nilainya sebesar 92,5 standar deviasinya 7,28 dan nilai variansnya 52,99 . Sedangkan kelas kontrol dengan jumlah anak 10 orang memperoleh nilai tertinggi 93,75 dan nilai terendah 75 . Dari nilai anak kelas kontrol ini diperoleh jumlah nilai secara keseluruhan yaitu 825 , median sebesar 82,3 dengan rata-rata nilainya sebesar 82,5 standar deviasinya 6,12 dan nilai variansnya 37,45 .

Untuk dapat menarik kesimpulan dari hasil penelitian, dilakukan uji hipotesis dengan menggunakan uji t. Sebelum uji t, terlebih dahulu dilakukan uji normalitas dan uji homogenitas terhadap hasil penelitian. Uji normalitas diperoleh dengan mengolah data tes akhir kelompok eksperimen dan kelompok kontrol. Uji normalitas dilakukan untuk mengetahui apakah sampel berdistribusi normal atau tidak. Untuk menguji normalitas digunakan uji liliefors.

Berdasarkan uji normalitas kelompok eksperimen dan kelompok kontrol menggunakan uji liliefors diperolah harga
L0 dan Lt pada taraf nyata 0,05 untuk $\mathrm{N}=10$ seperti pada tabel 3 .

Tabel 3. Hasil Perhitungan Pengujian Liliefors Kelas Eksperimen dan Kelas Kontrol

\begin{tabular}{|c|c|c|c|c|c|c|}
\hline $\begin{array}{l}\mathbf{N} \\
\mathbf{0}\end{array}$ & $\begin{array}{l}\text { Kelomp } \\
\text { ok }\end{array}$ & $\mathbf{N}$ & A & Lo & $\begin{array}{l}L \\
t\end{array}$ & $\begin{array}{c}\text { Keterang } \\
\text { an }\end{array}$ \\
\hline 1 & $\begin{array}{l}\text { Eksperi } \\
\text { men }\end{array}$ & 10 & 0,05 & 0,1469 & 0,258 & Normal \\
\hline 2 & Kontrol & 10 & 0,05 & 0,1987 & 0,258 & Normal \\
\hline
\end{tabular}

Berdasarkan tabel 3 terlihat bahwa kelas eksperimen nilai Lhitung 0,1469 lebih kecil dari $L_{\text {tabel }} \mathbf{0 , 2 5 8}$ untuk $\alpha=0,05$. Dengan demikian nilai kelas eksperimen berasal dari data yang berdistribusi normal. Untuk kelas kontrol diperoleh Lhitung $\mathbf{0 , 1 9 8 7}$ lebih kecil dari Ltabel $\mathbf{0 , 2 5 8}$ untuk $\alpha=0,05$. Ini berarti bahwa data kelas kontrol berasal dari data yang berdistribusi normal.

Uji homogenitas dilakukan dengan menggunakan uji barlett. Pengujian ini bertujuan untuk mengetahui apakah data berasal dari kelompok yang homogen, antara kelompok eksperimen dan kelompok kontrol. Jika chi kuadrat hitung < chi kuadrat tabel berarti data berasal dari kelompok yang homogen.

Hal ini sesuai dengan apa yang dikemukakan oleh syafril (2010:206) bahwa Jika hasil perhitungan dari $X^{2}$ hitung $<X^{2}$ tabel berarti data berasal dari kelompok yang homogen, sebaliknya jika $X^{2}$ hitung $>X^{2}$ tabel maka kelompok tersebut tidak homogen. Berdasarkan uji Homogenitas kelompok eksperimen dan kelompok kontrol diperolah harga $\chi^{2}$ hitung dan $\chi^{2}$ table pada taraf nyata 0,05 untuk $\mathrm{N}=10$ seperti pada tabel 4 
Tabel 4. Hasil Uji Homogenitas Kelas Eksperimen dan Kelas Kontrol

\begin{tabular}{ccccc}
\hline Kelompok & A & $\boldsymbol{\chi}^{2}$ hitung & $\boldsymbol{\chi}^{2}$ tabel & Kesimpulan \\
\hline Eksperimen & 0,05 & 0,207 & 3,841 & Homogen \\
\hline Kontrol & & & & \\
\hline
\end{tabular}

Dari tabel 4 terlihat bahwa $\chi^{2}$ hitung kelas eksperimen dan kelas kontrol lebih kecil dari $\chi^{2}$ tabel $\left(\chi^{2}\right.$ hitung $<\chi^{2}$ tabel $)$, berarti kelas eksperimen dan kelas kontrol memiliki varians yang homogen.

Setelah uji homogenitas dan uji normalitas, kemudian dilanjutkan dengan uji hipotesis bertujuan untuk mengetahui apakah terdapat perbedaan yang signifikan untuk nilai kedua kelompok. Menurut Syafril (2010:169) apabila thitung lebih besar dari tabel untuk $\alpha \quad 0,05$ berarti terdapat perbedaan yang signifikan untuk nilai hasil belajar tersebut. Apabila thitung lebih kecil atau sama dengan $t_{\text {tabel }}$ berarti tidak terdapat perbedaan yang signifikan pada hasil belajar tersebut.

Untuk menguji hipotesis digunakan $t$ test. Dari hasil uji hipotesis dengan menggunakan $t$-test diperoleh hasil yang bisa dilihat dalam tabel 5

Tabel 5. Hasil Perhitungan Post-test Pengujian dengan ttest

\begin{tabular}{|c|c|c|c|c|c|c|}
\hline $\begin{array}{l}\mathrm{N} \\
\mathrm{O}\end{array}$ & $\begin{array}{c}\text { Kelomp } \\
\text { ok }\end{array}$ & $\mathbf{N}$ & $\begin{array}{c}\text { Hasil } \\
\text { Rata- } \\
\text { rata }\end{array}$ & $t_{\text {hitung }}$ & $\begin{array}{c}T_{\text {tabel }} \\
\alpha 0,05\end{array}$ & $\begin{array}{c}\text { Keput } \\
\text { usan }\end{array}$ \\
\hline 1 & $\begin{array}{c}\text { Eksperi } \\
\text { men }\end{array}$ & 10 & 92,5 & $\begin{array}{c}3,164 \\
5\end{array}$ & $\begin{array}{c}2,100 \\
92\end{array}$ & $\begin{array}{c}\text { Tolak } \\
\mathrm{H}_{0}\end{array}$ \\
\hline 2 & Kontrol & 10 & 82,5 & & & \\
\hline
\end{tabular}

T tabel untuk taraf nyata $\alpha=0,05$ (5\%) dengan $\mathrm{df}$ sebesar 18 adalah = 2,10092. Dengan demikian, dapat diketahui bahwa pada taraf nyata $\alpha=0,05(5 \%)$, thitung lebih besar dari pada tabel $(\mathbf{3 , 1 6 4 5}>$ 2,10092). Jadi, dapat disimpulkan bahwa $\mathrm{H}_{\mathrm{a}}$ diterima dan $\mathrm{H}_{0}$ ditolak yaitu: terdapat perbedaan yang signifikan antara hasil posttest (hasil akhir) anak kelas eksperimen dan kelas kontrol dalam perkembangan bahasa lisan anak di Taman Kanak-kanak Darul Falah Kota Padang.

Perbandingan hasil perhitungan nilai pre-test dan post-test terlihat pada nilai tertinggi dan nilai terendah yang diperoleh anak dan terlihat pada rata-rata kelas eksperimen dan kelas kontrol pada posttest dimana post-test rata-rata menjadi lebih efektif dari rata-rata pre-test setelah dilakukan treatment. Untuk lebih jelasnya dapat dilihat pada grafik pada gambar 1

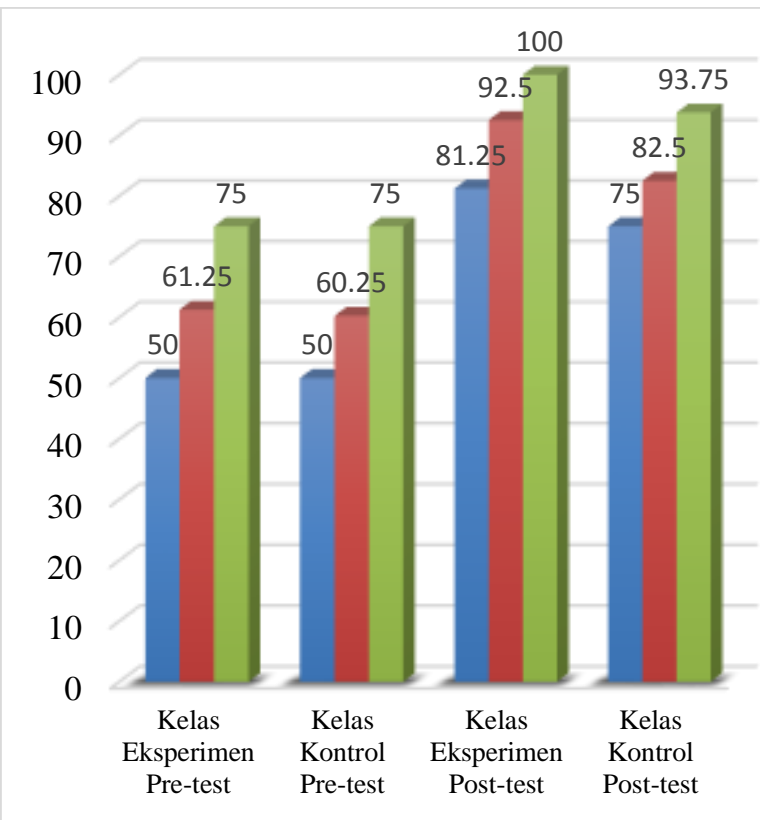

Nilai Terendah $\quad$ Rata-rata $\quad$ Nilai Tertinggi

Gambar 1. Data Perbandingan Hasil Pre-test dan Posttest Perkembangan Bahasa Lisan Anak Kelas Eksperimen dan Kelas Kontrol

Berdasarkan grafik di atas terlihat bahwa sebelum dilakukan post-test nilai yang didapat anak pada pre-test adalah nilai tertinggi pada kelas eksperimen adalah 75 dan kelas kontrol adalah 75 , nilai tertendah untuk kelas eksperimen adalah 50 dan kontrol 50, nilai rata-rata yang diperoleh anak adalah 61,25 untuk kelas eksperimen dan 60,25 untuk kelas kontrol. Setelah dilakukan post-test nilai anak meningkat pada kedua kelas. Perbandingan nilai terlihat pada kelas eksperimen berkembang lebih besar dibandingkan 
dengan kelas kontrol, yaitu nilai tertinggi yang berhasil dicapai anak pada kelas eksperimen adalah 100 sedangkan kelas kontrol 93.75 dan nilai terendah yang didapat anak pada kelas eksperimen 81,25 dan kelas kontrol 75. Selanjutnya nilai ratarata yang didapat oleh anak pada kelas eksperimen 92,5 sedangkan kelas kontrol 82,5 . Dan besaran efeknya dimana dihitung dengan rumus Cohen's d sebesar 1,488

Jadi dapat disimpulkan bahwa perkembangan bahasa lisan anak efektif dengan menggunakan metode bermain peran makro dibandingkan dengan metode bercakap-cakap, terlihat dari nilai pada rata-rata yang berhasil dicapai anak yaitu kelas eksperimen 92,5 sedangkan kelas kontrol 82,5. Bermain peran makro memiliki besaran pengaruh yang tinggi terhadap perkembangan bahasa lisan anak dikarenakan nilai Cohen's d besar dari $d=0,80$.

\section{Pembahasan}

Berdasarkan hasil pre-test perkembangan bahasa lisan anak pada kelompok eksperimen dan kelompok kontrol pada pre-test diperoleh angka ratarata kelompok eksperimen 61,25. Angka rata-rata kelompok kontrol 60,25. Berdasarkan hasil analisis data yang telah dilakukan bahwa thitung sebesar 0,147 dibandingkan dengan $\alpha$ 0,05 (ttabel = 2,10092) dengan derajat kebebasan dk (N1$1)+(\mathrm{N} 2-1)=18$. Dengan demikian thitung < ttabel yaitu 0,147 < 2,10092, maka dapat dikatakan bahwa hipotesis $\mathrm{Ha}$ ditolak atau Ho diterima. Jadi dapat disimpulkan bahwa tidak terdapat perbedaan yang signifikan antara hasil pre-test perkembangan bahasa lisan anak pada kelompok eksperimen dengan kelompok kontrol. ini berarti perkembangan bahasa lisan anak pada tes kemampuan awal (pre-test) sama atau tidak memiliki perbedaan yang signifikan.

Berdasarkan hasil akhir (post-test) perkembangan bahasa lisan anak setelah diberikan treatment melalui penerapan metode bermain peran makro dalam perkembangan bahasa lisan anak yang diberikan pada kelompok eksperimen dan kelompok kontrol diberikan treatment melalui metode bercakap-cakap diperoleh angka rata-rata kelompok eksperimen 92,5. Angka rata-rata kelompok kontrol 82,5. Berdasarkan hasil analisis data post-test yang telah dilakukan bahwa thitung sebesar 3,1645 dibandingkan dengan $\alpha 0,05$ (ttabel $=2,10092$ ) dengan derajat kebebasan $\mathrm{dk}$ $(\mathrm{N} 1-1)+(\mathrm{N} 2-1)=18$. Dengan demikian thitung > ttabel yaitu 3,1645 > 2,10092, maka dapat dikatakan bahwa hipotesis $\mathrm{Ha}$ diterima atau Ho ditolak. Dan uji besaran efek (effect size) diperoleh sebesar 1,488. Jadi dapat disimpulkan bahwa penerapan metode bermain peran makro berpengaruh terhadap perkembangan bahasa lisan anak. Hal ini terjadi karena dengan penerapan metode bermain peran makro kegiatan yang dapat membuat anak menjadi antusias, aktif, dan menjadikan proses pembelajaran lebih menarik dan menyenangkan bagi anak sehingga anak lepas dari suasana tertekan dan tidak terbebani. Dalam kegiatan ini anak meniru tokoh yang akan dimainkan dan anak melakukan interaksi menggunakan bahasa lisan dengan lawan mainnya, dalam hal ini akan mengajarkan anak menggunakan bahasa lisan dengan jelas saat berinteraksi dengan lawan mainnya dan mengajarkan anak bagaimana bahasa yang digunakan oleh tokoh yang sedang diperankannya di kehidupan sebenarnya. Sehingga penerapan metode bermain peran makro ini dapat menarik minat anak serta bermakna bagi anak dalam pembelajaran untuk perkembangan bahasa lisan anak.

Pendekatan ini memberi perhatian dalam menghubungkan pengalamanpengalaman pembelajaran yang bermakna bagi anak. Penggunaan metode bermain peran makro dengan menggunakan kegiatan restoran minuman anak bermain 
berdasarkan peran yang akan dimainkannya dan anak akan meniru baik bahasa maupun perilaku seperti tokoh tersebut dikehidupan sebenarnya. Pada kegiatan ini anak akan bermain dengan menggunakan alat-alat permainan yang besar atau alat permainan yang sesungguhnya seperti alat-alat kerumahtanggaan dan alat-alat yang mendukung dalam restoran minuman. Dalam menerapkan metode bermain peran makro untuk mengembangkan bahasa lisan anak, peneliti mangambil kegiatan restoran minuman. Dimana, dalam kegiatan restoran minuman tokoh yang akan di mainkan yaitu koki, pelayan, kasir, dan pembeli. Dengan kegiatan restoran minuman anak akan bermain restoran dengan alat-alat yang sudah disiapkan seperti baju koki, menu minuman, meja dan kursi restoran, serta alat-alat kerumahtanggaan yang sebenarnya. Pada kegiatan ini anak bermain berdasarkan skenario yang sudah dibuat oleh peneliti agar dalam pelaksanaannya lebih tertata dan beraturan ketika anak bermain.

Menurut Madyawati (2016:158) menyatakan bahwa bermain peran dapat mengembangkan kemampuan berbahasa, dimana saat bermain peran anak akan berbicara seperti karakter atau orang yang diperankannya. Hal ini dapat memperluas kosa kata anak sehingga membantu anak mengulangi dialog yang pernah didengarnya. Sejalan dengan itu Moeslichatoen dalam Amri (2017:106) mengatakan bahwa melalui kegiatan bermain peran anak dapat melatih kemampuan bahasanya dengan cara mendengarkan bunyi, mengucapkan suku kata, memperluas kosa kata serta berbicara sesuai dengan tata bahasa indonesia.

Selain itu, Musbikin dalam Pudjaningsih (2013:83), menyatakan bahwa standar perkembangan dasar dan indikator bahasa anak usia 5-6 tahun yaitu standar perkembangannya yang pertama adalah anak dapat berkomunikasi secara lisan, memiliki pembendaharaan kata, serta mengenal simbol-simbol untuk persiapan membaca dan menulis dengan perkembangan dasar yaitu anak dapat mendengar dan membedakan bunyi suara, kata, dan kalimat sederhana, dimana salah satu indikatornya yaitu menirukan kembali bunyi. Kedua, anak dapat berkomunikasi atau berbicara lancar dengan lafal yang benar dengan salah satu indikatornya adalah menyebutkan nama diri, orang tua, jenis kelamin, tanggal dan bulan kelahirannya, dan alamat rumah dengan lengkap serta anak berkomunikasi secara lisan dengan bahasanya sendiri. Amri (2017:106) juga berpendapat bahwa bermain peran anak dilatih untuk mengungkapkan ide, harapan, dan keinginan mereka sesuai imajinasi dengan batasan cerita atau peran yang diberikan. Metode bermain peran juga memberikan suasana baru bagi anak didik dalam proses pembelajaran yang dilakukan dalam suasana bermain tanpa terbebani oleh tugas perkembangannya.

Pada kelompok kontrol yang menggunakan metode bercakap-cakap, menurut Dhieni dalam Pudjaningsih (2013:87), menyatakan bahwa kegiatan bercakap-cakap dapat berarti komunikasi lisan antara anak dengan guru atau anak dengan anak melalui kegiatan monolog dan dialog juga dapat berarti saling mengomunikasi dengan bantuan gambar, sebagian besar anak kurang tertarik untuk melakukan kegiatan karena kebanyakan anak merasa kegiatan yang dilakukannya sama dari waktu ke waktu, serta membuat anak merasa bosan karena selalu menggunakan media serta metode yang sama dalam proses pembelajaran dan guru lebih banyak berbicara dibandingkan anak tentu hal itu membuat perkembangan bahasa lisan anak kurang berkembang..

Berdasarkan pengamatan peneliti, hasil perkembangan bahasa lisan anak di kelas eksperimen lebih baik daripada hasil 
perkembangan bahasa lisan anak di kelas kontrol, ini dapat dilihat dari rata-rata anak kelas eksperimen lebih tinggi dari kelas kontrol. Maka dapat disimpulkan bahwa penerapan metode bermain peran makro memberikan pengaruh yang signifikan terhadap perkembangan bahasa lisan anak.

\section{KESIMPULAN}

Berdasarkan hasil analisis data penelitian yang telah dilakukan, hasil penelitian diperoleh bahwa metode bermain peran makro berpengaruh terhadap perkembangan bahasa lisan anak di Taman Kanak-kanak Darul Falah Kota Padang. Hal ini terbukti bahwa metode bermain peran makro berpengaruh terhadap perkembagan bahasa lisan anak dengan nilai rata-rata dari kelompok eksperimen (B3) lebih tinggi $(92,5)$ dibandingkan kelompok kontrol (B4) yaitu $(82,5)$. Dan hasil uji hipotesis didapat $t_{\text {hitung }}>$ $t_{\text {tabel dimana } 3,1645>2,10092 \text { yang }}$ dibuktikan dengan taraf signifikan $\alpha=0,05$, serta dibuktikan dengan menghitung effect size dan uji $t$ sebesar 1,488, ini berarti terdapat perbedaan yang signifikan antara perkembangan bahasa lisan anak kemampuan kelompok eksperimen dan kelompok kontrol di Taman Kanak-kanak Darul Falah Kota Padang.

Berdasarkan hasil penelitian di atas, dapat dikemukakan beberapa saran sebagai berikut: 1) Bagi guru, metode bermain peran makro ini memberikan semacam hidden practise dimana anak tanpa sadar menggunakan ungkapan-ungkapan terhadap pembelajaran yang akan dicapai dan sedang mereka pelajari, metode ini memberikan kesenangan bagi anak karena pada dasarnya metode ini permainan, alatalat permainan yang digunakan juga mudah didapatkan, metode bermain peran makro merupakan pembelajaran yang bermakna bagi anak dan juga dapat mengembangkan perkembangan bahasa lisan anak. Oleh karena itu, guru dapat menciptakan kegiatan yang menyangkut untuk mengembangkan perkembangan bahasa lisan anak maka perkembangan bahasa lisan anak akan terasah dengan baik dan optimal; 2) Pihak Taman Kanak-kanak Darul Falah Kota Padang, meningkatkan kualitas pendidikan dan menjadi contoh bagi PAUD lain; 3) Kepada peneliti selanjutnya, hasil penelitian ini diharapkan dapat menjadi sumber bacaan atau panduan bagi peneliti lain untuk mengembangkan penelitian yang baru.

\section{DAFTAR PUSTAKA}

Akil, Muhammad \& Winata, Widia. (2017). Efektivitas Bermain Peran Untuk Pengembangan Bahasa Anak. Pembelajar: Jurnal Ilmu Pendidikan, Keguruan, dan Pembelajaran (Volume 1 Nomor 2).

Amri, Nur Alim. (2017). Pengaruh Bermain Peran Terhadap Kemampuan Komunikasi (Bahasa Ekspresif) Anak Taman Kanak-kanak Raudhatul Athfal Alauddin Makassar. Pembelajar: Jurnal Ilmu Pendidikan, Keguruan, dan Pembelajaran (Volume 1 Nomor 2)

Arikunto, Suharsimi. (2010). Prosedur Penelitian: Suatu Pendekatan Praktik. Jakarta: Rineka Cipta.

Madyawati, lilis. (2016). Strategi Pengembangan Bahasa Pada Anak. Jakarta: Kencana.

Pudjianingsih, Wiwik. (2013). Metode Pengembangan Bahasa: Penerapannya Pada Pembelajaran Berbasis Tema dan Sentra di Taman Kanak-kanak. Jurnal Pena (Vol. 3 No. 2).

Rumilasari, Tegeh \& Ujianti. (2016). Pengaruh Metode Bermain Peran (Role Playing) Terhadap Kemampuan Berbicara Pada Anak Kelompok A. $e$ journal PAUD Universitas Pendidikan Ganesha (Volume 4. No. 2). 
Safriayani, Hasanah. dkk. (2011). 99 Ide Kegiatan Main Peran. Jakarta: INDOCAMP.

Sugiyono. (2015). Metode Penelitian Pendidikan (Pendekatan Kuantitatif, Kualitatif, dan $R \& D)$. Bandung: Alfabeta.

Susanto, Ahmad. (2017). Pendidikan Anak Usia Dini (Konsep dan Teori). Jakarta: Bumi Aksara.

Syafril. (2010). Statistika. Padang: Sukabina Press. 